\title{
Inherited Haemoglobin Disorders Among Apparently Healthy Individuals- An Analysis of 105 Cases
}

Salsabil $M A^{1}$, Islam $M^{2}$, Jahan $D^{3}$, Khan $M^{4}$

\begin{abstract}
Introduction: Inherited hemoglobin disorders present a significant health problem all over the world. Due to migration, this problem is increasing day by day. No definitive data regarding the frequency of hereditary haemoglobin disorders are available in Bangladesh. Iron deficiency is most widely prevalent in the country and beta thalassaemia is also common.
\end{abstract}

Objective: The aim of the study is to determine the relative frequency of inherited haemoglobin disorders among apparently healthy individuals in two different institutes.

Methods: This observational cross-sectional prospective study was carried out in the Department of Haematology of Dhaka Medical College Hospital $(\mathrm{DMCH})$, Dhaka for a period of one year from January 2010 to December 2010. Apparently healthy physicians, staffs and students of Dhaka Medical College (DMC) as well as students of Dhaka University (DU) between 18 to 35 years age irrespective of sex were included in the study. Blood samples of specific amount were taken from all these individuals for estimation of $\mathrm{CBC}$, red cell variables and $\mathrm{Hb}$ electrophoresis.

Results: A total number of 105 respondents were enrolled in this study with the mean age of 25.2 years and female $(52.2 \%)$ predominance. $\mathrm{Hb}$ electrophoresis revealed normal $\mathrm{Hb}$ pattern in $89.4 \%$ individuals, $\mathrm{HbE}$ trait in $4.8 \%$, beta thalassaemia trait in $3.8 \%$. One each of Hereditary Persistence of Fetal Haemoglobin (HPFH) and heterozygous $\mathrm{Hb}-\mathrm{D}$ Punjab were detected constituting $2.0 \%$. In this present study, a total of $10.6 \%$ abnormal $\mathrm{Hb}$ pattern was detected.
Conclusion: The finding of abnormal $\mathrm{Hb}$ pattern on $\mathrm{Hb}$ electrophoresis in this study among apparently healthy individuals indicates the high frequency of inherited haemoglobin disorders especially $\mathrm{HbE}$ and beta thalassaemia trait in Bangladesh which warrants detection of these disorders and subsequent appropriate genetic counseling.

Key-Words: Inherited haemoglobin disorder, $\mathrm{Hb}$ electrophoresis, Genetic counseling.

\section{Introduction}

Inherited hemoglobin disorders especially thalassaemia and sickle-cell disorders were originally characteristic of the tropics and subtropics but these disorders are now common worldwide due to migration ${ }^{1}$. As programmes such as integrated treatment, carrier detection and genetic counseling are the most effective effort for controlling these disorders cost-effectively, World Health Organization (WHO) has recommended global development of these services and programme ${ }^{2}$.

Different types of inherited haemoglobin disorders present a significant health problem all over the world accounting $71 \%$ of 229 countries, and these $71 \%$ of countries include $89 \%$ of all births worldwide $^{2}$. About $7 \%$ of the world's population is a carrier of hemoglobin disorders ${ }^{3}$. In another study, it was observed that around 7000,000 babies are born each year with either a congenital abnormality or genetic diseases and most of the births occur in lowor middle-income countries ${ }^{4}$. Of these births, approximately $25 \%$ consist of only 5 disorders, among which, the inherited disorders of hemoglobin are monogenic diseases ${ }^{1}$.

1. Major Masuma Ahmed Salsabil, MBBS, FCPS, Classified Specialist in Pathology, AFIP, Dhaka; 2. Dr Manirul Islam, MBBS, FCPS, Asst Professor, Department of Haematology, Dhaka Medical College and Hospital, Dhaka; 3. Dr Dilshad Jahan, MBBS, FCPS, Asst Professor, Department of Haematology, Gonosastho Somajbhittik Medical College, Savar; 4. Prof Mohiuddin Ahmed Khan, FCPS, FRCP, Professor and Head, Dept of Haematology and BMT, Dhaka Medical College and Hospital ,Dhaka. 
Approximately more than of 300000 children are born each year with either sickle cell anaemia or one of its variants such as haemoglobin $E$ or a form of thalassaemia. It is difficult at present to provide an estimate about the health burden imposed by the major inherited haemoglobin disorders because of lack of information about the gene frequencies of these inherited disorders. In sub-Saharan Africa, about 180000 babies are born each year with sickle cell anaemia ${ }^{1}$. The serious forms of betathalassaemia are mainly beta-thalassaemia major and haemoglobin $E(\mathrm{HbE})$ beta-thalassaemia. Haemoglobin $\mathrm{E}(\mathrm{HbE})$ beta-thalassaemia occurs at a high frequency in parts of the Indian subcontinent, Bangladesh, Myanmar, and throughout Southeast Asia $^{4}$.

Data regarding the incidence of different forms of thalassaemias and haemoglobinopathies must be interpreted with caution as recent micromapping studies have indicated a remarkable heterogeneity in the distribution of the haemoglobin disorders, often within short geographical distances ${ }^{4}$. Recent data obtained from Sri Lanka as well as from two northwest states of India also show a noticeable variation in the frequency of beta thalassaemia and $\mathrm{Hb} \mathrm{E}^{5,6}$.

In Bangladesh, no definitive data regarding the frequency of hereditary haemoglobin disorders are available. A conservative World Health report estimates that $3 \%$ populations in Bangladesh are carrier of B-thalassaemia gene which means that there are 3.6 millions carrier of beta thalassaemia gene in Bangladesh ${ }^{7}$. $\mathrm{Hb} \mathrm{E}$ is quite common in Bangladesh $^{8}$.There are 4.8 millions carriers of $\mathrm{HbE}$ in Bangladesh. Affected birth per thousand of beta thalassaemia and $\mathrm{HbE} /$ beta thalassaemia are 0.106 and 3.00 respectively. It is presumed that approximately six thousands thalassaemic children are born each year in Bangladesh ${ }^{8}$.

Iron deficiency is most widely prevalent in the country and beta thalassaemia is also common. Both produce microcytic hypochromic blood picture of the red cell which is one of the commonest abnormalities that a clinician may encounter in their professional practice in this country. Iron deficiency may co-exist with bêta thalassaemia trait and this association is common in Bangladesh. Iron deficiency in beta thalassaemia trait lower the $\mathrm{HbA}_{2}$ level causing the detection of beta thalassaemia trait difficult by haemoglobin electrophoresis. Thalassaemia is considered the most common genetic disorder worldwide ${ }^{10}$. The disease is highly prevalent in Mediterranean countries, Middle East, Southern and Eastern Asia, the South Pacific and South China with reported carrier rates ranging from $2 \%$ to $30 \%{ }^{11}$

Carriers of inherited haemoglobin disorders are usually asymptomatic and go unnoticed without any major clinical manifestation. As the incidence of such inherited haemoglobin disorders are common in Bangladesh, therefore to reduce the burden of such disorders, it is recommended to make the people of all walks of life aware and conscious about the disease through mass and electronic Medias. These inherited haemoglobin disorders are hereditary and pass from one generation to next generation; it is advisable to carry out population based screening and subsequent genetic counselling.

These programmes should be carried out at national level with the help of different non-government health organizations. Government can pass and impose rule to perform premarital health screening mandatory before marriage for some common inherited disorders in this country among the prospective couples. In this way it is possible to lessen the incidence of inherited haemoglobin disorders in our country and thereby alleviate the social agony and economic burden from the health budget. The aim of this present study is to find out the relative frequency of various haemoglobin disorders in apparently healthy young individuals as well as to create awareness among them about the disease and also to provide genetic counselling for future planning in their prospective conjugal life.

\section{Materials and Methods}

This prospective cross-sectional study was carried out in the Department of Haematology, Dhaka Medical College Hospital (DMCH) from January 2010 to December 2010. A total of 105 apparently healthy individuals irrespective of sex from 18 to 35 years of age were included in this study. This individuals included students, doctors, nurses from Dhaka Medical College Hospital (DMCH) and also students from Dhaka University (DU). 
Initially, all the individuals were informed about the aims, design and procedure of the study. Individuals who did not give consent and who have known haemoglobin disorders and also family history of haemoglobin disorders were excluded from this study. Informed consent was taken from all the participants and the ethical issues were approved by the institutional ethical committee.

A total of two milliliter venous blood from antecubital vein was taken in a vacutainer containing three milligram Ethylene Diamine Tetra Acetic Acid (EDTA) for complete blood count and haemoglobin electrophoresis. Complete blood count was done by automated haematology analyzer (Sysmex $\mathrm{KN}-21 \mathrm{~N}$ ). Before running the sample the analyzer was calibrated daily in the morning by low normal, normal and high normal supplied by the manufacturer. Haemoglobin level, Haematocrit (Hct), Mean Cell Volume (MCV), Mean Cell Haemoglobin $(\mathrm{MCH})$ and Mean Cell Haemoglobin Concentration $(\mathrm{MCHC})$ were recorded for further analysis.

Peripheral blood film was prepared from all the samples of complete blood count and haemoglobin electrophoresis and examined under microscope for microcytic hypochromic blood picture. Haemoglobin electrophoresis was done gradually in batches of all samples using Sebia 2 Flex piercing capillary electrophoresis. All the pertinent data of complete blood count and haemoglobin electrophoresis were entered into Statistical Package for (SPSS) version 16 for further analysis. Confidence limit was 95\% and probability value $<0.05$ was considered as significant.

\section{Results}

A total of 105 respondents irrespective of sex between 18-35 years of age are included in this study. Table-I shows the demographic data of the responders. Among 105 patients maximum are from the age group of $25-29$ years which is $50(47.5 \%)$ cases followed by less than or equal to 24 years and more than equal to 30 years which are $43(41.0 \%)$ cases and $12(11.5 \%)$ cases respectively. The mean age of the study population is $25.21 \pm 3.73$ with a range of 20.0-38.0. In this study female is predominant than male which is $55(52.4 \%)$ and $50(47.6 \%)$ cases respectively.
Table-I: Demographic data of the respondents $(n=105)$.

\begin{tabular}{|c|c|c|}
\hline \multicolumn{2}{|c|}{ Age Group (in years) } & Number (\%) \\
\hline \multicolumn{2}{|c|}{$\bullet \cdots \cdots \cdots$} & $43(41.0 \%)$ \\
\hline \multicolumn{2}{|l|}{$25-29$} & $50(47.5 \%)$ \\
\hline \multicolumn{2}{|c|}{$\bullet \cdots \cdots \cdots$} & $12(11.5 \%)$ \\
\hline \multirow{2}{*}{ Sex } & Male & $50(47.6 \%)$ \\
\hline & Female & $55(52.4 \%)$ \\
\hline
\end{tabular}

Table-II and Table-III show mean \pm SD of RBC, $\mathrm{Hb}$, $\mathrm{MCV}, \mathrm{MCH}$ and $\mathrm{MCHC}$. The mean RBC is $4.89 \pm$ $0.58 \times 10^{12} / \mathrm{L}$ with a range of $3.87-6.58 \times 10^{12} / \mathrm{L}$.The $\mathrm{Hb}$ is $13.25 \pm 2.12 \mathrm{~g} / \mathrm{dl}$ with a range of $6.60-17.90 \mathrm{~g} / \mathrm{dl}$. The mean MCV is $80.32 \pm 8.76 \mathrm{fl}$ with a range of $33.80-91.00$. The mean $\mathrm{MCH}$ is $27.65 \pm 6.37 \mathrm{pg}$ with a range of $14.00-84.30 \mathrm{pg}$. The mean $\mathrm{MCHC}$ is $33.43 \pm 1.54 \mathrm{~g} / \mathrm{dl}$ with a range of $26.10-36.20 \mathrm{~g} / \mathrm{dl}$.

Table-II: Pattern of red cell variables $(n=105)$.

\begin{tabular}{|l|c|c|}
\hline Variables & Mean \pm SD & Range \\
\hline $\mathrm{RBC}$ count $\left(\mathrm{X} 10^{\mathrm{y}}\right)$ & $4.89 \pm 0.58$ & $3.87-6.58$ \\
\hline $\mathrm{Hb}(\mathrm{g} / \mathrm{dl})$ & $13.25 \pm 2.12$ & $6.60-17.90$ \\
\hline $\mathrm{MCV}(\mathrm{fl})$ & $80.32 \pm 8.76$ & $33.80-91.00$ \\
\hline $\mathrm{MCH}(\mathrm{pg})$ & $27.65 \pm 6.37$ & $14.00-84.30$ \\
\hline $\mathrm{MCHC}(\mathrm{g} / \mathrm{L})$ & $33.43 \pm 1.54$ & $26.10-36.20$ \\
\hline
\end{tabular}

Table-III: Red Cell Variables in Male and Female $(n=105)$

\begin{tabular}{|l|c|c|}
\hline Variables & Male $(\mathbf{n}=\mathbf{5 0})$ & Female $(\mathbf{n}=55)$ \\
\hline $\mathrm{RBC}$ count & $5.30 \pm 0.47$ & $4.52 \pm 0.39$ \\
\hline $\mathrm{Hb}(\mathrm{gm} / \mathrm{dl})$ & $14.62 \pm 1.89$ & $12.01 \pm 1.45$ \\
\hline $\mathrm{MCV}(\mathrm{fl})$ & $81.11 \pm 6.62$ & $79.61 \pm 10.34$ \\
\hline $\mathrm{MCH}(\mathrm{pg})$ & $27.58 \pm 2.92$ & $27.71 \pm 8.38$ \\
\hline $\mathrm{MCHC}(\mathrm{g} / \mathrm{L})$ & $33.92 \pm 1.49$ & $33.00 \pm 1.46$ \\
\hline
\end{tabular}

In this study, the commonest pattern of haemoglobins found on capillary $\mathrm{Hb}$ electrophoresis is normal haemoglobin (89.4\%) followed by $\mathrm{HbE}$ trait $(4.8 \%)$. Table-IV shows the haemoglobin patterns found in the present study.

Table-IV: Distribution of the pattern of Haemoglobin on capillary $\mathrm{Hb}$ electrophoresis $(n=105)$.

\begin{tabular}{|l|c|c|}
\hline Pattern of Haemoglobins & Frequency & $\mathbf{( \% )}$ \\
\hline Normal & 94 & 89.4 \\
\hline Hemoglobin E trait & 5 & 4.8 \\
\hline Beta Thalassaemia trait & 4 & 3.8 \\
\hline HPFH & 1 & 1.0 \\
\hline Heterozygous Hb D-Punjab & 1 & 1.0 \\
\hline Total & 105 & 100.0 \\
\hline
\end{tabular}


The red blood cell variables are compared with the findings of capillary $\mathrm{Hb}$ electrophoresis. The common parameters of red blood cell such as Total Red Blood Cell (TRBC), Hb concentration; MCV, $\mathrm{MCH}$ and $\mathrm{MCHC}$ are found normal in 94 (89.5\%) cases and abnormal in $11(10.5 \%)$ cases. Table-IV shows the comparison of red cell variables with capillary $\mathrm{Hb}$ electrophoresis.

Table-V: Comparison of Red Cell Variables and Capillary Hb Electrophoresis $(n=105)$.

\begin{tabular}{|l|c|c|c|c|}
\hline Variables & Normal $(\mathbf{n}=94)$ & Abnormal $(\mathbf{n}=11)$ & $\boldsymbol{p ~ v a l u e}^{*}$ & Comment \\
\hline $\mathrm{TRBC}\left(\mathrm{X} 10^{\mathbf{9}} / \mathrm{L}\right)$ & $4.88 \pm 0.57$ & $5.00 \pm 0.66$ & 0.522 & Significant \\
\hline $\mathrm{Hb}(\mathrm{g} / \mathrm{dl})$ & $13.45 \pm 2.06$ & $11.55 \pm 1.89$ & 0.004 & Significant \\
\hline $\mathrm{MCV}(\mathrm{fl})$ & $81.59 \pm 7.89$ & $69.46 \pm 8.63$ & 0.001 & Significant \\
\hline $\mathrm{MCH}(\mathrm{pg})$ & $28.16 \pm 6.43$ & $23.30 \pm 3.64$ & 0.016 & Significant \\
\hline $\mathrm{MCHC}(\mathrm{g} / \mathrm{L})$ & $33.43 \pm 1.57$ & $33.44 \pm 1.29$ & 0.996 & Significant \\
\hline
\end{tabular}

${ }^{*} t$ test was done to measure the level of significance.

\section{Discussion}

A total number of 105 respondents of age 18-35 years with both sexes were enrolled in this study. The mean $\pm S D$ of $\mathrm{RBC}, \mathrm{Hb}, \mathrm{MCV}, \mathrm{MCH}$ and $\mathrm{MCHC}$ is recorded in this study. The mean TRBC is $4.89 \pm$ $0.58 \times 10^{12} / \mathrm{L}$ with a range of $3.87-6.58 \times 10^{12} / \mathrm{L}$. The $\mathrm{Hb}$ is $13.25 \pm 2.12 \mathrm{~g} / \mathrm{dl}$ with a range of $6.60-17.90 \mathrm{~g} / \mathrm{dl}$. The mean MCV is $80.32 \pm 8.76 \mathrm{fl}$ with a range of $33.80-91.00 \mathrm{fl}$. The mean $\mathrm{MCH}$ is $27.65 \pm 6.37 \mathrm{pg}$ with a range of $14.00-84.30 \mathrm{pg}$. The mean $\mathrm{MCHC}$ is 33.43 $\pm 1.54 \mathrm{~g} / \mathrm{dl}$ with a range of $26.10-36.20 \mathrm{~g} / \mathrm{dl}$. The mean \pm SD of TRBC, Hb, MCV, MCH and MCHC by comment on the basis of $\mathrm{Hb}$ electrophoresis is recorded in this study. The mean RBC is $4.88 \pm 0.57$ and $5.00 \pm 0.66$ in normal and abnormal cases respectively $(p=0.522)$. The $\mathrm{Hb}$ is $13.45 \pm 2.06$ and $11.55 \pm 1.89$ in normal and abnormal cases respectively $(p=0.004)$. The mean MCV in normal and abnormal cases is $81.59 \pm 7.89$ and $69.46 \pm 8.63$ respectively $(p=0.001)$. The mean $\mathrm{MCH}$ is $28.16 \pm$ 6.43and $23.30 \pm 3.64$ in normal and abnormal cases respectively $(p=0.016)$. The mean $\mathrm{MCHC}$ is $33.43 \pm$ 1.54 and $33.44 \pm 1.29$ in normal and abnormal cases respectively $(p=0.996)$. The mean $\pm S D$ of $R B C, H b$, $\mathrm{MCV}, \mathrm{MCH}$ and $\mathrm{MCHC}$ by comment on the basis of $\mathrm{Hb}$ electrophoresis according to sex is recorded. The mean RBC is $5.30 \pm 0.47$ and $4.52 \pm 0.39$ in male and female respectively $(\mathrm{p}=0.001)$. The $\mathrm{Hb}$ is 14.62 \pm 1.89 and $12.01 \pm 1.45$ in male and female respectively $(p=0.001)$. The mean MCV in male and female is $81.11 \pm 6.62$ and $79.61 \pm 10.34$ respectively $(p=0.374)$. The mean $\mathrm{MCH}$ is $27.58 \pm 2.92$ and 27.71 \pm 8.38 in male and female cases respectively $(p=0.916)$. The mean MCHC is $33.92 \pm 1.49$ and $33.00 \pm 1.46$ in male and female respectively $(p=0.002)$. Haematological findings in inherited haemoglobin disorders are varied in haemoglobin electrophoresis. The distribution of the study population according to age is recorded in this study. Among 105 patients maximum are from the age group of $20-30$ years $(47.6 \%)$ followed by less than equal to 20 years $(41.0 \%)$ and more than equal to 30 years $(11.5 \%)$. The mean age of the study population is $25.21 \pm 3.73$ (range $=20.0-38.0$ year). Similar result was reported by Weatherall and Clegg and added that at the younger age group inherited haemoglobin disorder are most commonly detected $^{12}$. Modell and Darlison (2008) also found a result which is consistent with the present study ${ }^{1}$. The distribution of the study population according to sex is recorded in this study. In this study female $(52.4 \%)$ is predominant than male $(47.6 \%)$. Similar result was reported by Colah et al (2010) and mentioned that the female is most commonly affected by haemoglobin inherited disorders ${ }^{6}$. Weatherall and Clegg (2001) also found a similar result ${ }^{12}$.

Types of $\mathrm{Hb}$ Disorder on the basis of Hemoglobin electrophoresis is endorsed in this study. Among 105 cases majority are normal $(89.4 \%)$ followed by hemoglobin $E$ trait $(4.8 \%)$, beta thalassemia trait (3.8\%). HPFH and heterozygous Hb-D Punjab are only $1.0 \%$ cases in each. Weatherall and Clegg (2001) were reported similar result and mentioned that over 700 structural haemoglobin variants have been identified and only three reach high frequencies which are $\mathrm{Hb} \mathrm{S}, \mathrm{Hb} \mathrm{C}$, and $\mathrm{Hb} \mathrm{E}$. In another study, Fucharoen and Winichagoon (1998) reported that Haemoglobin $E$ is the commonest structural haemoglobin variant globally and thalassemia is the extremely common which is presenting an increasingly important health problem in many parts of $\mathrm{Asia}^{13}$.

\section{Conclusion}

In South East Asia, inherited haemoglobin disorders are one of the most common inherited disorders and put tremendous burden to the national budget. Most of the carriers remain asymptomatic and pass relatively normal life. Through population based screening programmes, it is recommended to screen 
all healthy individuals to detect such asymptomatic carriers and to provide genetic counseling. It may also be passed regulations through the government that premarital testing which also include MCV \& subsequently $\mathrm{Hb}$-electrophoresis on the basis of MCV result should be done compulsory of the prospective couples before marriage.

\section{References}

1. Modell B, Darlison M. Global epidemiology of haemoglobin disorders and derived service indicators. Bull World Health Organ; 2008; $6(86),: 480-7$.

2. World Health Organization. Thalassaemia and other haemoglobinopathies. Agenda item 5.2. 6. In: 59th World Health Assembly, 27 May 2006. EB118.R1. Avaliable from: http://www.who.int/gb lebwha/pdf_fles/EBSS-EB118-2006-REC1/english/R es/reseb118_2006_rec1-en.pdf [accessed on 6 February 2008.

3. Thalassaemia International Federation, Guidelines for the clinical management of thalassaemia, 2008; 1-5.

4. Weatherall, D.J.The inherited diseases of haemoglobin are an emerging global health burden. Blood 2010; 115(22):4331-6.

5. de Silva S, Fisher CA, Premawardhena A, Thalassaemia in Sri Lanka: implications for the future health burden of Asian populations. Sri Lanka Thalassaemia Study Group. Lancet, 2000; 9206(355): 786-91.

6. Colah R, Gorakshakar A, Phanasgaonkar Epidemiology of beta thalassaemiain Western India: mapping the frequencies and mutations in sub-regions of Maharashtra and Gujarat [published online ahead of print March 3, 2010]. Br J Haematology doi:10.1111/j.2010;1365-2141.

\section{Khan MA. Thalassaemia in Bangladesh DS (Child). HJ1999; 15:42-4.}

8. Rahman MJ, Rahman MH. Prevention \& control strategy of thalassemia in Bangladesh. The ORION Medical Journal 2003; 16:121-22

9. Madan, N., M. Sikka Haematological parameters and $\mathrm{HbA}_{2}$ levels in beta-thalassaemia trait with coincident iron deficiency J Lab Clin Med 1998; 56:866.

10. Greer, J., Foester, J., Glader, B. et al. 2004. Wintrobe's Clinical Haematology, Andrews NC. Iron deficiency and related disorders, 11th ed. 2004; 42: 982-1319.

11. Hoffbrand, A.V, Catovsky, D and Tuddenham, EGD. Post gradu ed2004; 42:982-1319ate Haematology. In: Mark N and Hoffbrand AV. Iron metabolism, iron deficiency and disorders of haem synthesis. 5th ed, 2005 Blackwell publishing Limited;31:85-9.

12. Weatherall, D. J. and J. B. Clegg. Inherited haemoglobin disorders: an increasing global health problem. Bulletin World Health Organization, 2001,79:704-12.

13. Fucharoen S, Winichagoon P. Hemoglobinopathies in South-east Asia: molecular biology and clinical medicine. Hemoglobin, 1997; 21: 299-319. 